\title{
Albanians in Confrontation with the Challenges of World War I
}

\author{
Ma. Veli Kryeziu, PhD. Cand \\ Public University "Hasan Prishtina" \\ No.31, 10 000, Prishtina \\ Republic of Kosovo
}

\begin{abstract}
The Balkans as a geographic whole could not resist not being involved in World War I taking into account that the Balkan countries themselves encouraged the Great Powers revolt in reaction to the assassination of the Austria's heir in June 1914 in Sarajevo. Bosnia's annexation from Austria-Hungary was not easily accepted by Serbia, and this was the reason for the assassination of Prince Franz Ferdinand. From the warring parties, "Battlefield" - Albania suffered the most loss, this did not have any impact on this war, but the consequences for it were great, each of the warring parties had the intention to occupy Albania. The Civil Wars for bajraktarism (system of territorial and military organization along patriarchal clan lines) among Albanians were the worst that happened to Albania. The nonexercise of sovereignty by the Government of Vlora as well as the escape of Vid from Albania left the country at the mercy of fate and captains of the Essad time. The Balkan wars were pulse measurement of whoever could take from neighbors, so the Serbian-Montenegrin and Greco-Italian goals towards Albania were more than reasonable because they had long since plotted plans for the collapse of Albania, namely the establishment of the Great Greece (Megalithic idea) and Great Serbia (Načertanija 1844), where it was seen within the Serbian borders: Bosnia, Montenegro, Northern Albania, Kosovo and Macedonia. Serbia had fed its ideology of fabrication "Serbian Kosovo" respectively "Kosovo - the cradle of Serbia", the idea that Kosovo should be Serbian and that Serbia should be its successor has incited violence, murder, ethnic cleansing of Albanians by local Serbs in Kosovo or even Serbs coming as a column, organized and instrumentalized continuously by Serbia's král (king). The Serbian pseudo-history always tried to distort the historical facts about Kosovo, but it is impossible to kill a whole people in order to assimilate, exterminate and expel through ethnic cleansing. In 1911 official records of Young Turks which could not be hidden by Serbia, the Vilayet of Kosovo had a total of 912,902 inhabitants, out of which 106,209 were Serbs, 56,396 Bulgarians and about 7,000 were Jevgs and Jews, while 743,040 were Albanian autochthonous population. Albanians due to the high birthrate and readiness to preserve national identity managed to withstand the bloody Balkan wars.
\end{abstract}

Keywords: Albania, Serbia, Austria-Hungary, Bulgaria; Balkan Wars, World War I, etc.

A newly created Albania, and even partitioned, incomplete (as outside its borders remained Kosovo, Chameria and other territories in Macedonia, Montenegro and Serbia) according to unfair decisions by the London Conference of 1913 (Kokolari, 1943:20). Undoubtedly, it was unorganized politically and weak militarily, but with great efforts to preserve their territory, this situation was preceded by the escape of Vid from Albania, this made Albanians organize the General Council in Shijak (Bartl, 1999:170). On January 22, 1914, the provisional government of Vlora was forced to resign from the inability to unify the people and extend sovereignty throughout the territory of Albania; therefore they agreed to pass their powers to the International Commission of Control (Smirnova, 2004:69). The First World War broke out as a pretext for the assassination of the heir of Austrian throne Franz Ferdinand in Sarajevo on June 28, 1914 by a Serbian nationalist organization, a month later Austro-Hungary declared war on Serbia, whereby the First World War broke out between Austria-Hungary and Germany on one side and England, France and Russia on the other (Instituti i Historisë dhe i Gjuhësisë, 1965:417). The whole war had an imperialistic aim (Imperialism - the highest and the last stage of capitalism with tendency to win monopoly, influence over a certain territory, war for division of the world etc), invading and dividing as many territories as possible (Dhama \& Kurti, 1989:85).

\section{Albania on the eve of World War I}

Faced with the challenge of World War I and the problems of pretenders (Albanian traitors) for obstructing the institutional development of Albania, Albanian rebels were challenged both by foreign and domestic enemies, it was Esad Pasha Toptani who returned from the exile in Italy via Serbia in 1914 in order to prevent the recovery of the Albanian state. Poverty on the one hand and civil conflicts on the other stopped the steps of Albania in the early years of its birth (Puto, 2009:113). The Austro-Hungarian army soon reached Serbia and even entered Kosova territory, with little resistance came into northern Albania as well, respectively in Shkodra and a part of middle Albania, while the Italian army during December 1914 invaded Vlora and continued the deployment of forces in Durrës, Gjirokastra, etc. 
French forces penetrated from Thessaloniki, where they faced the Bulgarian and German armies which expelled them from the South of Albania and occupied a strategic position in Korça and the shores around Lake Pogradec (Zavalani, n.d.:252). Austria-Hungary also occupied Albania in an effort to fight Serbia and Montenegro, it seems clear that Albanians, oppressed by an Empire which was forced to flee from where it had arrived, could not resist a wellorganized army such as Austria-Hungary, therefore they were forced to accept some sort of submission to AustroHungarian troops (Rexha, 2011:148). Albania became a battlefield and its territory was divided between the warring forces, Italy invaded the South of Albania (Puto, 2003:76), all this and the Italian invasion of Albanian lands can not be justified otherwise than as an imperialistic goal of time to conquer Albania, Italy is as guilty as Greece and Serbia for secret treaties (Çami, 1987:13). Serbia tried to move the war against Austria-Hungary to its south, but during this time Bulgaria also declared war on it, this event did not escape Albanians' attention, they were organized in Kaçak rebellious groups to save Albania, this rebellion was extended to Qafë Thanë of Albania (Rushiti, 1986:89); in January 1915, under the direction of Hasan Prishtina, the rebellion was extended up to Gjakova's highlands (Rushiti, 2003:169); from where Serb forces were forced to retreat leaving behind the traces of crime committed against the civilian population, Serbia even claimed that Albania had declared war on Serbia, in February 1915, the newspaper Dielli in Boston wrote: "Though temporary attacks by Albanians in the border area were made, according to a telegram from Niš, which was also published in the European and American press, it was estimated that Albania had declared war on Serbia and that the Albanian army had allegedly attacked its territory. According to the newspaper Dielli, no war declaration was officially made by Albania, but the publication of this telegram was made to satisfy Serbian appetite" ("Dielli," 1915).

It is difficult to say that Albania declared war on Serbia as long as it has not been able to recover itself, and even more when all foreign services have been spread within it as well as its armies that have transformed Albania into fighting arena. Koha newspaper wrote: "Who can think of the miserable Albanians of Kosovo who are being slaughtered by the Serbian yataghan when today more than ever anarchy reigns in Albania?"....the writing goes on like this: "Thus, being left miserable, in the streets and persecuted, and without hope, they grabbed the weapons again seeking death better than an unbearable life under the rule of Serbian barbarians! This is the cause of these revolts that broke out today" (“Koha," 1915).

The Italians collaborated with the Serbs and the French throughout the war, so the Serbs penetrated into Dibër and southern Albania; Esad Pasha benefited from these circumstances and created some kind of power in a part of Albania (Bajrami, 2000:16). The newspaper " Flamuri i Shqipërisë", which was published in Constanţa, wrote: "Esadd embarrassed the Albanian name; he did not honor his word. He who grew up in Sultan's school..., damn it all, - damn it Essad, the orphans' kidnapper, the oppressor of the poor, the denier of the right, the oppressor of freedom, the liar of the people..., the murderer of Riza Pasha, the Judah of Shkodra, the causer of bloodshed, the traitor of Albania, forever damned the tyrant of Tirana" (Devolli, 1916:1).

\section{Serbo-Montenegrin invaders}

Serbo-Montenegrins as invasive structures in the Albanian villages and towns began to expand the military police administration in order to prepare the terrain for a long-term invasion, their structures launched a search campaign of Albanian leaders in order to capture them and suppress the uprisings. The Serbo-Montenegrin army's conduct was inhuman (Kasumaj, 2003:177). The Serbo-Montenegrin invaders used the violent conversion of Albanian Muslims and Catholics to Orthodox as a tool of organized violence, these monstrous crimes were made with the consent of the king of Montenegro Nikola Petrovic and that of Serbia Peter Karadjordjevic, the conversion was carried out by the Serbian church (Bajrami, 2004:125). Serbian forces tried to find an accomplice (Albanian traitor) on all fronts of the war, so on June 1, 1915, the commander of the Serbian forces met Ahmet Muhtar Pasha, the Albanian leader of Mat, in the village Selishtë near Dibra, Tafë Kazi a Serbian collaborator was also present in the meeting, the request of the Serbian officer Mijuskovic from Ahmet was that people of Mat hand over the weapons and accept the Serbian army in that territory as according to him the Serbian army can penetrate even with war to suppress the danger that Serbia was facing from the people of Mat at the borders, but Ahmet Pasha said that people of Mat were not going to hand over their weapons and accept foreign invaders, on the contrary Albanians know how to protect themselves..., but in those circumstances his determination changed and agreed that Mat be under the Serbian rule, that people of Mat hand over their weapons to Mladen Stamatovic, and not to resist against Serbia, the leader of Mat asked to meet Pašić to get his support against Essad Pasha (Rahimi, 1982:197). On June 2, 1915, secured by a military convention with Essad Pasha, the Serbian army marched from Macedonia to Albania, where they faced strong resistance from Haxhi Qamili. In that period, Montenegrins also went to Shkodër (Bartl, 1999:171). 


\section{The invasion of Shkodra}

For the occupation of Shkodra by the Serbo-Montenegrin chauvinists, the newspaper Dielli wrote "The Serbian Government in Shkodra", in the same article, it wrote: Paris, November 25 - "The Serbian Embassy announced that the Serbian government was removed from Prizren and went to Shkodër". A telegram from Berlin says that the king of Serbia Peter received an invitation from the Prince of Montenegro Nicholas to come to Cetinje and govern Serbia. "Some statements by a Serbian minister", the Serbian minister of war who is now in Thessaloniki claimed up to 35,000 deaths or wounded and 20,000 captives, but there are 200,000 more and we will continue the war even in the mountains of Albania or Montenegro ("Dielli", 1915). "Komiteti i fshehtë" ("The Secret Committee") led by Hoxha Kadriu suffered a serious blow, most of them were scattered throughout other parts of Albania (Skëndi, 1992:25). With the intensity of World War I, Austro-Hungarian forces made progress in the terrain so that Montenegro was forced out of this war in January 1916 and accepted the capitulation before Austria-Hungary (Smirnova, 2004:84).

The Austro-Hungarian army entered triumphally in Shkodra on January 23, 1916 and started step by step progress on the rest of Albania, such as: Tirana, North Albania, Dukagjini, Kosovo Plain, Drenica and Llap (Dërvishi, 2006:71). The newspaper "Vëllazënija" wrote: "The Liberators of Shkodra"..., "We entered in Shkodra yesterday evening. Several thousand Serbs, who were in the city, fled south without a shotgun"("Vëllazënija", 1916). Based on this article, published by "Dija", it is said that the Albanian people and Albania finally saw the light since the Austro-Hungarian army expelled Albania's enemies Serbian-Montenegrins from our lands.

In areas occupied by Austro-Hungarians, Vienna gave Albanians the cultural autonomy led by her, from this view, it undertook a series of measures to educate and raise Albanians, its main pillar was the formation of the General Directorate of Education based in Shkodra, whose director was Luigj Gurakuqi (Koliqi, 2002:326).

The Albanian colony of Vienna expresses thanksgiving telegram to the Austro-Hungarian army deputy Kuvasz Generaloberst to honor him on the occasion of the liberation of Albania ("Vëllazënija", 1916).

According to a convention for territorial division signed on September 6, 1915 in Plesë, Albanian territories and especially Kosova unfortunately remained under separate occupation in the Austro-Hungarian occupation zone and in the area of Bulgarian rule. Austria-Hungary and Germany were obliged to give Bulgaria the eastern and southern part of Serbia, Macedonia, and most of Kosovo (Rushiti, 1986:93), but since the time of these two warring states in the Balkans, Austria-Hungary did not exert violence against Albanians (Rexha, 2011:148). Austro-Hungarians had more favorable treatment of Albanians compared to the Bulgarians (Kosova në vështrimin monografik, 2001:228). Since the early days of the Bulgarian administration, they began mistreating Albanians by burning their houses, imposing repressive measures with the pretext of seeking and handing over weapons by Albanian rebels whose head was Idriz Seferi and his comrades (Rexhepi, 2015:254). In addition to the ongoing war and military pressures, Albanians also faced political efforts of the Great Powers, which had drafted the Secret Treaty of London presented on November 15, 1915 which foresaw broken Albania according to the wishes of the devouring neighbors such as: Italy, Greece, Serbia and Montenegro, but they could not implement this project (Çami, 1986:122).

\section{Kosova under Austro-Hungarian and Bulgarian rule}

Austro-Germans had promised Albania that if they win the war, Albania will join a single territory (Arifi, 2017:12). Even the Austrian emperor himself promised that to the Albanian leader from Kosova, Hasan Prishtina, the latter in the areas dominated by the Austrians made efforts both in terms of national liberation, as well as for the opening of schools in the mother tongue for the people of Kosova (Shala, 2014:101). In Kosova, the first attempts were made to open schools in Albanian, this was very important since Albanian children in Kosova for the first time started learning the Albanian alphabet, which had long been approved at the Congress of Manastir (Rushiti, 1986:93). Hasan Pristina established contacts with the insurgents of Kachak movements; on the basis of these efforts he had invited for a talk the military leader Azem Bejta Galica, for the purpose of coordinating the Albanian factor to fight the invaders.

Unlike the Austro-Hungarians, the Bulgarians in eastern Kosova and the part of Macedonia in the name of requisition began to take Albanians the cereals and agricultural goods, and so the civilian population was overwhelmed by hunger. In the district of Ferizaj, more than half of the population was left without bread (Rushiti, 1986:95). June 1915 found Isa Boletini in the district of Shkodra, exactly at the French consulate, the Serbo-Montenegrins found the location of Isa Boletini and made observations, but the Consul of France in Shkodra was not to be trusted because the Government of this consulate was in support of Serbia and Montenegro throughout World War I. The French consul proposed to Isa to go to Cetinje, where the Montenegrin government decided to shelter him and his family members in Niksic, while sending the rest of Albanians to Podgorica. 
During all the time they stayed in Montenegro, they were almost under arrest by Niksic, Isa Boletini was sent to another town as Niksic had fallen into the hands of Austria-Hungary, during the movement, it was constantly thought by the Montenegrin gendarmerie how to execute Isa Boletini and other Albanian leaders who were in Montenegro (Musaj, 2015:189). In January 1916, in Montenegro, the organization of the murder of Albanian patriot Isa Boletini and his son was reported; his death was a big loss for the Albanian people because he was the leader of all the uprisings in the territory of Kosova (Myftiu, 2012:252).

The newspaper "Dielli" wrote "The Evropean War" - through which Austria declares Serbia's utter defeat which means that Serbia no longer stands as an independent state ("Dielli", 1916). The Austro-Hungarian army on 22 February 1916 issued a decree of 8 points stating: "We have not come to Albania as enemies, the people here trust us, so we should use this trust to strengthen the Austro-Hungarian position in this country by respecting the habits of the inhabitants and we should be an example as an army of a civilized state" (Kocaqi, 2016:141). Knowing that Austro-Hungary has always looked at Albania with a positive eye, thanks to her the Albanian people in the ruling areas by AustroHungarians enjoyed national rights, peace and security without any threat of danger (Bajrami, 2008:229). After the Literary Commission of Shkodra was established, with the permission of the military command, the newspaper "Posta e Shqypnies" started to be published in two languages German and Albanian. Albania, in confrontation with warring powers, was forced to host and conquer invaders that were replaced such as Serbs, Montenegrins and Greeks with Austro-Hungarians, Bulgarians and Italians, but none of these had good intentions for Albania and Albanians. This situation continued until the fall of 1916 where gradually the Greek forces were replaced with the French and Italian forces (Çami, 1987:219).

At the end of 1916, movements of Serb forces were investigated in the Kopaonik and Rogozin region in North Mitrovica, which started an activity against the Albanian administration. From these Serbian efforts, it seemed proper for Albanians to move to protect the land from Serbs (Boletini, 1996:12). Serbia gradually began to recover and come to the fore of a Balkan order with the help of French, English and Russian allies and undertook actions towards a reorganization that began to apply in the field (Rexhepi, 2005:112). Though helpless and tired of lack of food and general economic conditions, the Albanians made constant resistance to the old Serbo-Montenegrin invaders or new invaders (Abdyli, 1994:25). The Serbian government migrated during the years 1914-1916 followed by its army headquarters, Serbia claimed that after the First World War, based on the Declaration of Niš in December 1914, there will be within its borders Kosova and a part of Albania (Murzaku, 1996:127). The weakening of Bulgaria forced the latter to seek peace, in an article of the newspaper "Dielli" wrote: "Bulgaria wants peace", this kind of peace and instant cease-fire was requested by the Pope in a speech and an appeal sent to the Warring Powers, it does not give up her rights in Macedonia, but at the same time likes the Pope's proposal for peace ("Dielli", 1917).

With the capitulation of Bulgaria, summer-autumn 1918, the French and Serbian army were continuing the pursuit of the Austro-Hungarian Army, the Franco-Serbian army arrived in Vranje ("Dielli", 1918). Many captives, balls and machine guns fell into their hands; they entered Kumanova, Skopje, Ferizaj, Gjilan, Prizren and Peja. A report by the French government published in the newspaper "Dielli" wrote: "The French and Serbian armies are persistently pursuing the Austro-Germans who flee before the allied attacks. In Albania, some Serbian military divisions are continuing their advances, in another title: "Dibra fell into the hands of Serbs," the article continues: "The Frenchmen reached 35 miles from the border of Northern Albania. The Allies could hit the Austrians from Dibra and leave them with no one to be of help before they leave Albania" ("Dielli", 1918).

Kachak Movements in Kosova established contacts with Serbian insurgents in 1917, talks were held in Krushumli on February 20, 1917 between Albanians and Serbs, aiming to co-ordinate military forces against the Austro-Hungarian invaders, this cooperation of Albanians continued until the end of 1918, the year that marks the end of World War I and the full re-occupation of Kosova by Serbia (Rushiti, 1986:103).

\section{Conclusion}

From historiographic literature and the press of time during World War I, it is concluded that Albania as a geographic term and its strategic position played an important role in World War I. Albania's neutrality in this war featured by Vid was the wisdom of the time, Albanians were also lucky that the Austria-Hungary itself preserved the neutrality of Albania, although they did not easily escape from this war.

Since the Congress of Berlin 1878 and later the Congress of London 1913, Albania and its leaders were not free to choose. The International Commission of Border imposed borders to Albania. From this injustice, Kosova, Albanian Macedonia, and Malesia e Madhe remained outside ethnic lands. It is difficult to describe events from an angle when you are not the decision maker but the cannon fodder, only Albanians had this luck, Serbs while leaving AustriaHungary from 1914 to 1915 across Albania invented defeat by not declaring and not being punished for the barbarous massacres they committed in Kosova, Dukagjin and Has, while crossing Albania. 
They even continued to criminalize the civilian population of Lume, Opoja, and Dibra. An army organized and accompanied by its king while walking through Albanian residence committing crimes against humanity and not being punished for the crimes committed, cannot be justified otherwise than a genocidal state such as Serbia, which must be denounced for genocide against Albanians and as such to pay the damages of World War I.

Albanians have never stopped their national unification efforts since 1878 when unjustly Plave, Gusinje, Ulcinj, Antivari, etc. remained outside Albania, continuing with the famous Congress of Ambassadors in London from 1912 to 1913, even the Peace Conference of Paris had the same tendencies towards Albania. On this occasion, it is worth mentioning the Albanian friend the President Wilson who on November 3, 1920 told the warring states that with Albania could no longer play anybody, rejecting the aspirations of Yugoslavia and Greece. The year 1920 marks the officiality of Albania Independence, recognized by the United States headed by the President Wilson. Kosova and other populated Albanian territories remained under Yugoslav rule until the 1990s of the 20th century.

\section{References}

Arifi, S. (2017). Austro-gjermanët për çështjen shqipëtare 1908-1918. Prishtina: Lena Graphik Design.

Avdyli, R. (1994, 3 4). Politika serbe e gjenocidit ndaj Kosovës dhe shqiptarëve. Kosova-Political historical journal. Bajrami, H. (2000). Ibrahim Gjakova, shtyllë e Komitetit të Kosovës. Prishtina: Vatra.

Bajrami, H. (2018). Shqipëtarët në luftë për shtet kombëtar 1912-1918. Prishtina: Faik Konica.

Bajrmai, H. (2004). Politika pansllaviste serbe në luften për shfarosjen e shqiptarëve 1836-1999. Vjetar.

Barlt, P. (1999). Shqipëria nga mesjeta deri më sot. Prizren: Drita.

Bartl, P. (1999). Shqipëria nga mesjeta deri më sot. Prizren: Drita.

Boletini, T. (1996). Përballë sfidave të kohës, Kujtime II, 1916-1963. Tetovo: Album.

Bullgaria do paqe. (1917, gusht 27). Dielli, 2.

Çami, M. (1986). Shqipëria në marrëdhënjet midis vendeve të Antantes. Studime Historike.

Çami, M. (1987). Shqipëria në mardhëniet ndërkombëtare 1914-1918. Tirana: Akademia e Shkencave RPS të Shqipërisë, Instituti i Historisë.

Destanu, B., \& Tomas, J. (2012). Miku i madhë i shqipëtarëve Aubrey Herbert dhe krijimi i Shqipërisë së sotme Ditarë dhe letra 1904-1923. (K. Myftiu, Përkth.) Tirana: Via Egnatia.

Devolli, K. (1916, Mars 1). Tiran' i Tiranës. Flamur' i Shqipërisë, , 1.

Dërvishi, K. (2006). Historia e shtetit shqipëtarë, 1912-2005, Organizimi shtetëror, jeta politike, ngjarjet kryesore, të gjithë ligjëvensit, ministat dhe kryetarët e shtetit shqipëtarë. Tirana: 55.

Dhama, T., \& Kurti, V. (1989). Fjalor shpjegues i termave historike. 8 Nëntor. Franqest dhe serbet hynë në Vranjë. (1918, Tetor 8). Dielli, 1.

Kasumaj, H. (2003). Robërit shqiptarë të luftës si pengje të Serbisë dhe Malit të Zi gjat vitit 1912- 1915. Kosova.

Kocaqi, E. (2016). Administrimi i Shqipërisë nga Austro-Hungaria 1916-1918. Tirana: Emal.

Kokolari, H. (1943). Kosova djep i shqiptarizmit. Tirana: Masagjerit shqiptare.

Kokolari, H. (1943). Kosova djep i shqiptarizmit. Tirana: Masagjerit shqiptare.

Koliqi, H. (2002). Historia e arsimit dhe mendimit pedagogjik shqipëtar. Prishtina: Universiteti i Prishtinës / Libri Shkollor.

Kosova në vështrimin monografik. (2001). Prishtina: Akademia e Shkencave dhe e Arteve e Kosoveës.

Liruesi i Shqypënisë. (1916, Marc 18). Vëllazënija, 1.

Lufta evroipiane. (1916, Shkurt 4). Dielli, 1.

Lufta shqiptaro - serbe. (1915, February 25). Koha, 1.

Lufta Shqiptaro-Serbe. (1915, Shkurt 22). Dielli.

Murzaku, T. (1996). Kosova dhe çështja e çlirimit dhe e bashkimit kombëtar në vitet 1913-1918”, Çështja e Kosovës një problem historik dhe aktual. Tirana: Instituti i Historisë - Prishtinë \& Instituti i Historisë - Tirana.

Musaj, F. (2015). Isa Boletini, Akademia e Shkencave e Shqipërisë. Tirana: Instituti i Historisë.

Piter, B. (1999). Shqipëria nga mesjeta deri sot . (S. Berbatovci, Përkth.) Prizren: Drita.

Puto, A. (2003). Sfidat e pavarësisë së Shqipërisë. Kosova.

Puto, A. (2009). Shqipëria politike1912-1939. Tirana: Botimet Toena.

Qeveria serbe në Shkodër. (1915, nëntor 25). Dielli, 1.

Rahimi, S. (1981). Bashkëpunimi i Ahmet Muhtarit nga Mati me Serbinë dhe mospajtimet e tijë me Esat Pashë Toptanin gjatë vitit 1915. Gjurmime albanologjike- seria e shkencave historik.

Rexha, S. (2011). Raportet shqiptaro - serbe në Kosovë, : shtëpia botuese. Prishtina: 1953.

Rexhepi, F. (2015). Zona okupuese bullgare e Kosovës gjatë Luftës së Parë Botërore. Studime shoqërore.

Rexhepi, R. (2005). Seferi ndër shekuj monografi. Gjilan. 
Rushiti, L. (1986). Gjendja ekonomike dhe politike në Kosovë gjatë luftës së parë Botërore. Kosova.

Rushiti, L. (2003). Rezistenca e popullit shqiptarë kunder pushtuesëve serbo-malazes 1912-1914. Kosova.

Skëndi, E. (1992). Hoxhë Kadriu (Kadri Prishtina). Prishtina: Rilindja.

Smimova, N. (2004). Historia e Shqipërisë për gjatë shekullit XX. Tirana: Ideart .

Smirniva, N. (2004). Historia e Shqipërisë për gjatë shekullit XX. Tirana: Ideart.

Shala, X. (2014). Hasan Prishtina vështrim i shkurtës atdhetarie. Prishtina: 1953.

Todi , D., \& Kurti, V. (1989). Fjalor shpjegues i termave historike. Tirana: 8 Nëntori.

U lirue Shkodra! (1916, Kallënduer 28). Vëllazënija, 1.

Universiteti Shtetëror i Tiranës - Instituti i Historisë dhe i Gjuhësisë. (1965). Historia e Popullit Shqiptarë 2,. Prishtina: Enti i Botimeve Shkollore i RSS Reparti Prishtinë.

Universiteti Shtetëror i Tiranës - Instituti i Historisë dhe i Gjuhësisë. (1965). Historia e Popullit Shqiptarë 2 . Prishtina: Enti i Botimeve Shkollore i RSS.

Zavalani, T. (a.d.). Histori e Shqipnis. Shkodër: Phoenix.

Zhapaj-Ikonomi, A. (2010). Marrëdheniet familje-shkollë, faktor i rëndësishëm në integrimin social dhe të ardhmen e fëmijëve me aftësi të kufizuara. Educologia, 351. 